\title{
BIOPHYSICAL INTERACTIONS IN THE CABO FRIO UPWELLING SYSTEM, SOUTHEASTERN BRAZIL
}

\author{
Sergio Augusto Coelho-Souza ${ }^{1,2 *}$, Maria Soledad López $z^{3}$, Jean Remy Davee Guimarães ${ }^{2}$, \\ Ricardo Coutinho ${ }^{l}$ and Rogério Nader Candella ${ }^{I}$
}

${ }^{1}$ Instituto de Estudos do Mar Almirante Paulo Moreira (IEAPM)

(Rua Kyoto, 253, 28930-000 Praia dos Anjos, Arraial do Cabo, RJ, Brasil)

${ }^{2}$ Universidade Federal do Rio de Janeiro - Instituto de Biofísica Carlos Chagas Filho (IBCCF/UFRJ)

(Bloco G, SL 49, 21949-902 Centro de Ciências e Saúde, Ilha do Fundão, RJ, Brasil)

${ }^{3}$ Universidade de São Paulo - Centro de Biologia Marinha (CEBIMAR/USP)

(Rod. Manoel Hipólito do Rêgo, Km 131,5, 11600-000 São Sebastião, SP, Brasil)

Corresponding author: sergio.coelhosouza@gmail.com

\begin{abstract}
A B S TR A C T
The rising of cold water from deeper levels characterizes coastal upwelling systems. This flow makes nutrients available in the euphotic layer, which enhances phytoplankton production and growth. On the Brazilian coast, upwelling is most intense in the Cabo Frio region (RJ). The basic knowledge of this system was reviewed in accordance with concepts of biophysical interactions. The high frequency and amplitude of the prevailing winds are the main factor promoting the rise of South Atlantic Central Water, but meanders and eddies in the Brazil Current as well as local topography and coast line are also important. Upwelling events are common during spring/summer seasons. Primary biomass is exported by virtue of the water circulation and is also controlled by rapid zooplankton predation. Small pelagic fish regulate plankton growth and in their turn are preyed on by predatory fish. Sardine furnishes an important regional fish stock. Shoreline irregularities define the embayment formation of the Marine Extractive Reserve of Arraial do Cabo making it an area with evident different intensities of upwelled water that harbors high species diversity. Consequently, on a small spatial scale there are environments with tropical and subtropical features, a point to be explored as a particularity of this ecosystem.
\end{abstract}

\section{RESUMO}

Os sistemas costeiros de ressurgência são caracterizados pela ascensão de águas frias que tornam os nutrientes disponíveis na camada eufótica para o crescimento e aumento da produção fitoplanctônica. No Brasil, a região do Cabo Frio (RJ) é o principal sistema de ressurgência costeira. O objetivo desse artigo foi revisar o atual conhecimento desse sistema através dos conceitos sobre interações biofísicas. A ascensão da Água Central do Atlântico Sul ocorre devido à alta frequência e amplitude dos ventos, à presença de meandros e vórtices na Corrente do Brasil, além da topografia local e da linha de costa. Os eventos de ressurgência são comuns durante os períodos de primavera/verão e a biomassa primária é exportada devido à circulação da água, sendo também controlada pela rápida predação zooplanctônica. Os pequenos peixes pelágicos regulam o crescimento do plâncton e são consumidos pelos peixes predadores, resultando em um importante estoque pesqueiro regional. A irregularidade da costa define as enseadas do Cabo Frio, na Reserva Extrativista Marinha do Arraial do Cabo, apresentando distintas influências das águas ressurgidas e resultando em grande diversidade de espécies. Consequentemente, ambientes com características tropicais e subtropicais são observados dentro de uma pequena escala espacial, o que constitui uma particularidade desse ecossistema.

Descriptors: Physical oceanography, Primary production, Trophodynamics, Benthic community, Conservation, Coastal management.

Descritores: Oceanografia física, Produção primária, Trofodinâmica, Comunidade bentônica, Conservação, Manejo costeiro. 


\section{INTRODUCTION}

Biophysical interactions are clearly evident in upwelling systems. The rising of deep cold water makes nutrients available for primary production in the euphotic zone where mass and energy are transferred through trophic webs (LEHMANN; MYRBERG, 2008). Further, water temperature variations structure trophic webs (DALY; SMITH JR., 1993).

Physical processes are important in the structuring of biological communities and for particle fluxes on both large and small spatial scales. Biological processes are more important on small spatial and temporal scales, since vertical migration and predation control planktonic production (DALY; SMITH JR., 1993). Furthermore, primary biomass is controlled both by physical (atmospheric, oceanographic and geomorphological) and biological (ecological interactions) factors. The main factors involved in primary producer regulation are hydrodynamics, phytoplankton physiology and adaptability, as well as zooplankton predation (DALY; SMITH JR., 1993; DENMAM; GARGETT, 1995).

The most productive areas in the ocean are the upwelling regions on the western coasts of the Americas and Africa (SMITH, 1968). In the Eastern Boundary Current systems cold bottom water rises from moderate depths as a result of the combined effects of trade winds, Coriolis force and Ekman transport. The Benguela and Humboldt systems have the highest Ekman transport with the greatest upwelling intensity, although the Benguela system presents the higher chlorophyll $a$ concentrations (ARNTZ et al., 2006).

Primary production is linked to thermocline topography since the latter coincides with the nutricline. Sattelite images indicate that primary production is at its highest in the Benguela and Canary systems, being followed by the Humboldt and California regions, respectively (PENNINGTON et al., 2006). However, the marine ecosystem off Peru is the main producer of fish biomass, yielding more than 20 times the tonnage produced by other upwelling systems (BAKUN; WEEKS, 2008).

Coastal upwelling is very common around the world. In Brazil, coastal upwelling areas are observed in seven regions along the southeastern/southern coast (Vitória, São Tomé, Cabo Frio, São Sebastião, Santa Catarina, Santa Marta and Rio Grande do Sul). The upwelling intensity is highest in the Cabo Frio region (Rio de Janeiro state) that has an extension of 150-400 Km from Arraial do Cabo city contrasting with an extension of $70 \mathrm{Km}$ on the Santa Catarina coast (KAMPEL et al., 1997). This paper discusses relevant regional studies undertaken on the Cabo Frio upwelling system. We hope to contribute to discussions of perspectives and future research on the main Brazilian upwelling ecosystem.

\section{Physical Dynamics And the \\ Oceanographic UpWelling Process IN THE CABo Frio System}

In coastal upwelling regions, stratification stability is a function of temperature and water currents. The mixing of superficial and deep waters occurs due to combination of vertical distribution velocity and water density (ALLEN, 1980; WINANT, 1980). On the Brazilian coast, the rising of the South Atlantic Central Water (SACW) determines the upwelling event in the southeastern-southern region. Consolidation of the SACW occurs in the Subtropical Convergence region $\left(33-38^{\circ} \mathrm{S}\right)$, in the confluence zone of the Malvinas and Brazil Currents (STRAMMA; PETERSON, 1990). SACW is transported by the South Atlantic Current to the African coast, where it joins the Benguela and Agulhas Currents (Fig. 1). SACW is also important in the Benguela and Canarias upwelling systems (PELEGRÍ et al., 2005) and turns back towards the South American coast around 16$20^{\circ} \mathrm{S}$ flowing northwards with the North Brazil Undercurrent and southwards with the Brazil Current (STRAMMA; ENGLAND, 1999).

Brazilian upwelling events are more pronounced in the Cabo Frio upwelling system $\left(23^{\circ} \mathrm{S}\right.$, $42^{\circ} \mathrm{W}$; Fig. 1) and are more frequent and intense during austral spring and summer seasons, mainly by virtue of the prevalence of the northeasterly (NE) winds (CASTELÃO; BARTH, 2006; CALADO et al., 2008). However, other factors might also be important, including: 1) seasonal variations of the Brazil Current's (BC) position (STRAMMA; PETERSON, 1990); 2) the geostrophic balance determining the vertical movements of the SACW (SIGNORINI, 1978); 3) coastal water suction due to BC eddies, and 4) introduction of SACW onto the continental platform induced by meanders of the BC (CAMPOS et al., 2000).

The change in the line of the coastline from north-south to east-west defines the Cabo Frio region and this configuration brings continent and continental platform together (Fig. 2). Both coastline geometry and bottom oceanic topography influence the magnitude of the upwelling (RODRIGUES; LORENZETTI, 2001). The topography of the ocean bed also increases the energy and activity of mesoscale eddies (CALADO et al., 2010). 


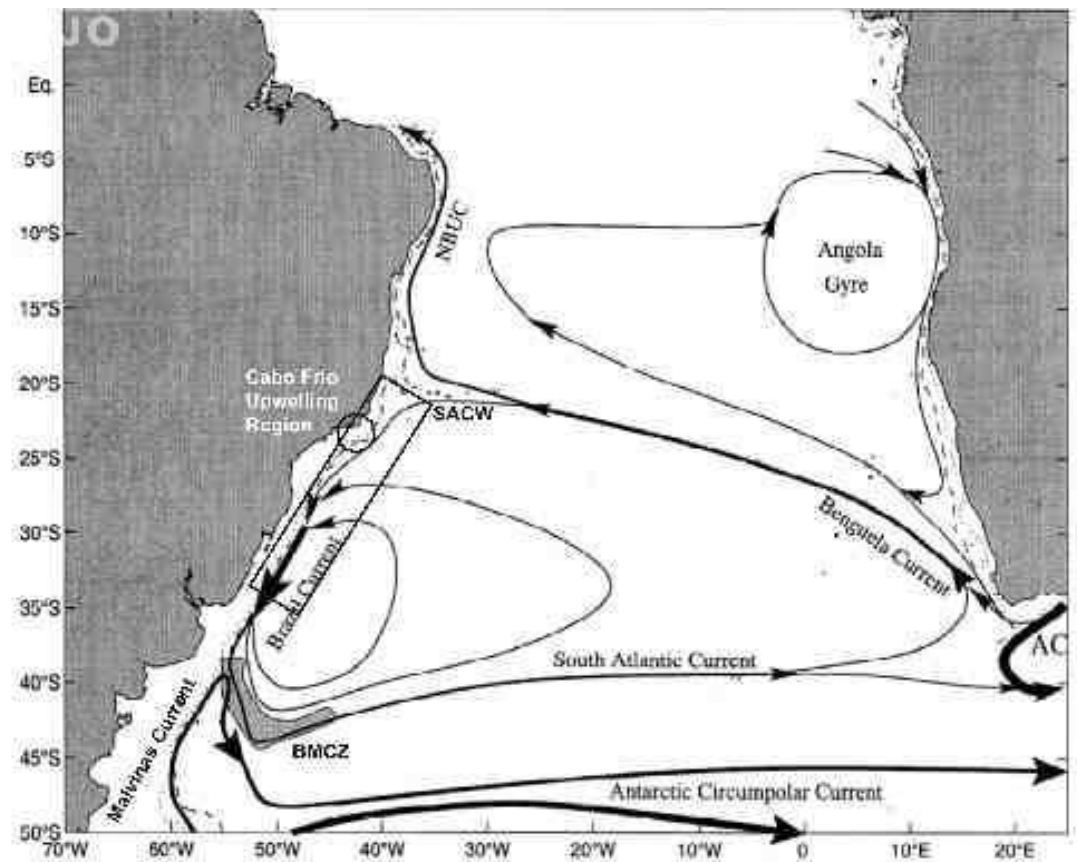

Fig. 1. Representation of the South Atlantic Central Water (SACW) geostrophic current at about 100 to $500 \mathrm{~m}$ depth. The region of the formation of this water mass in the Brazil-Malvinas Confluence Zone (BMCZ) is shaded. The Brazil, Malvinas, Antarctic Circumpolar, South Atlantic, Benguela and Agulhas (AC) Currents and the North Brazil Undercurrent (NBUC), as well as the Angola and Brazil gyres are also shown. The circle indicates the Cabo Frio Upwelling Region and the rectangles represent upwelling processes along the Brazilian coast (Adapted from Stramma and England, 1999).

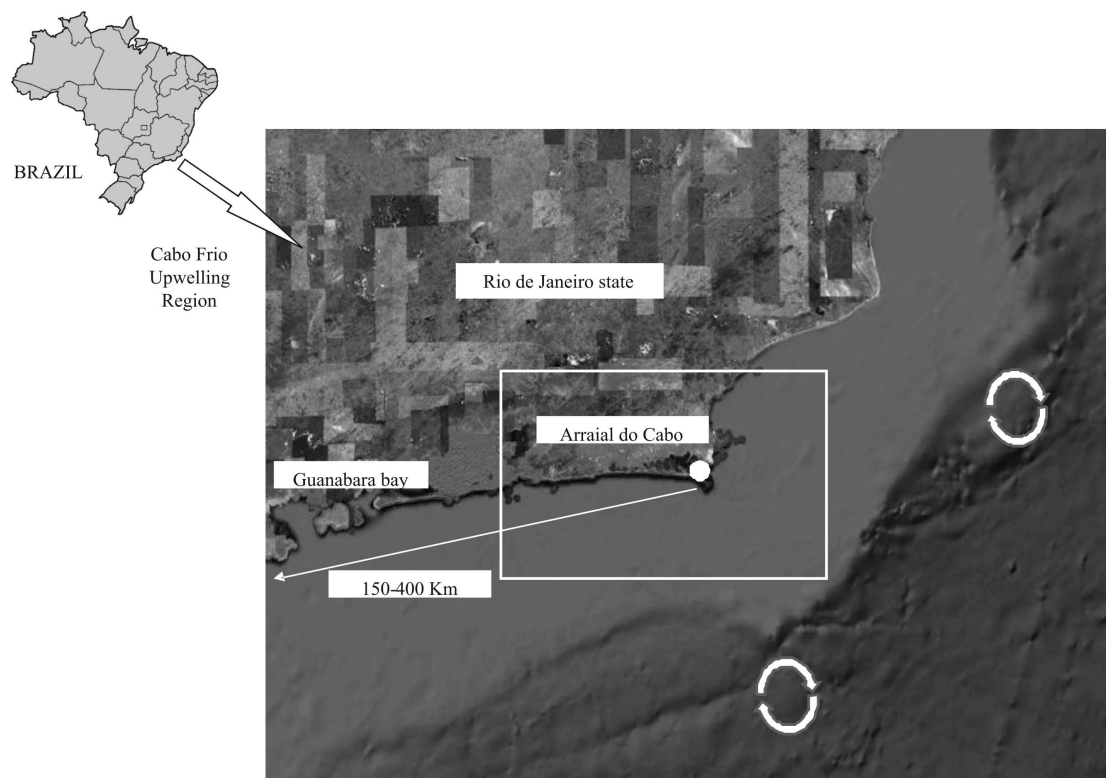

Fig. 2. The Cabo Frio upwelling region (white rectangle). White arrow shows the extension of upwelling events within 150-400 Km of Arraial do Cabo (Rio de Janeiro state). White circles represent meanders and eddies in Brazil Current (CAMPOS et al., 2000). Modified from Google Earth $^{\circledast}$. 
A yearly variation in upwelling processes has been observed on the Chilean coast (RUTLLANT; MONTECINO, 2002), as well as in the Cabo Frio system (Elias, unpublished data), and both were associated with El Niño/La Niña events. Oceanicatmospheric physical processes are also essential to the peculiar climate that determines the semi-arid vegetation of the Cabo Frio region and which contrasts with that of other parts of the Brazilian coast (FRANCHITO et al., 1998; 2007; 2008). This is an expected pattern since desert or arid adjacent land areas are commonly found in the regions of upwelling systems (ODUM, 1983).

\section{Physical-Biological Interactions: Ecological Consequences of Upwelling}

Plankton Biomass and Productivity

Upwelling productive areas generally present: 1) a high amplitude and frequency of auxiliary energy (usually the mechanical energy of the wind); 2) a high covariance of irradiation and nutrient concentration, and 3) a temporal or spatial delay in the interaction between primary and secondary producers (DALY; SMITH JR., 1993). Although the Cabo Frio upwelling system has high amplitude and frequency of wind auxiliary energy, the advection force is surely an important factor regulating phytoplankton biomass (VALENTIN et al., 1987a) since phytoplankton blooms can last less than one day (CARBONEL, 2003). Further, rapid zooplankton growth increases herbivory pressure (VALENTIN, 1984a; MCMANUS et al., 2007).

Since irradiance is rarely a limiting factor, Valentin (2001) considered that the biomass and primary production observed in the Cabo Frio system are lower than those of the major upwelling systems due to its reduced surface heating of upwelled water. The heating and mixture of SACW favor diatom and nanophytoplankton production (GONZALEZ-RODRIGUEZ, 1994; GONZALEZRODRIGUEZ; TENEMBAUM, 1995; GUENTHER et al., 2008). Also, the heterotrophic/autotrophic ratio and the viral abundance are negatively correlated with temperature (PEREIRA et al., 2010).

While the thermocline in the Cabo Frio system usually oscillates around $12-14 \mathrm{~m}$, in the Peruvian coastal upwelling it shoals to $\leq 40 \mathrm{~m}$ and both very often break the surface (PENNINGTON et al., 2006). The coldest temperature in the Cabo Frio region is around $13-14{ }^{\circ} \mathrm{C}$, but it oscillates around 12$16^{\circ} \mathrm{C}$ in the Chilean upwelling system (MONTECINO et al., 2004).
Nutrient concentrations are one of the main factors causing variability in the production of upwelling environments (GONZALEZ-RODRIGUEZ; MAESTRINI, 1984; ARNTZ et al., 2006; PENNINGTON et al., 2006; BAKUN; WEEKS, 2008; PATTI et al., 2008). SACW has a higher temperature and lower nutrient concentrations at Cabo Frio as compared to the water of the Benguela system, since nitrate values fall from $30 \mu \mathrm{M}$ in the Benguela system (BROWN; FIELD, 1986) to as little as $18 \mu \mathrm{M}$ in the Cabo Frio region (GONZALEZ-RODRIGUEZ et al., 1992). In the Canary Is. system, the SACW has a higher nitrate concentration than the North Atlantic Central Water, a water mass that upwells from 700 $\mathrm{m}$ in the northern region above $21^{\circ} \mathrm{N}$ (PELEGRÍ et al., 2005).

On the other hand, the highest primary biomass and production have been found in the oldest upwelling waters with $12-16{ }^{\circ} \mathrm{C}$ and $0-2 \mu \mathrm{M}$ of nitrate in the Benguela system (BROWN; FIELD, 1986). Both primary biomass and production were strongly correlated below $12 \mathrm{mg} / \mathrm{m} 3$ of chlorophyll $a$. The authors suggested that primary production was limited by low phytoplankton biomass in cold and fresh upwelling coastal waters and by nutrients and light in in oceanic areas. Furthermore, protozoan grazing regulates the phytoplankton stock to near constancy and surface layer recycling of fixed nitrogen as ammonia suppresses nitrate utilization so that it is never completely used up (MILLER, 2004).

Iron is another element that can regulate phytoplankton growth and composition since it can determine nitrogen and silicate incorporation (DUGDALE; WILKERSON， 1998; HUTCHINS; BRULAND, 1998). Miller (2004) has suggested that iron limits the size of phytoplankton. On the Peruvian coast, iron is a limiting nutrient for phytoplankton growth (BRULAND et al., 2005). In the Cabo Frio system, nitrate is the main limiting nutrient but phosphate and to a lesser degree iron and molybdenum are also important in the regulation of phytoplankton biomass growth (GONZALEZ-RODRIGUEZ, 1991).

Chlorophyll $a$ concentrations reported in the main upwelling area of the Cabo Frio region varied between 0.5 and $6.0 \mathrm{mg} / \mathrm{m}^{3}$ (GONZALEZ-RODRIGUEZ et al., 1992; PEREIRA et al., 2009a) but a value of 21 $\mathrm{mg} / \mathrm{m} 3$ was observed during a microalgae bloom in the Cabo Frio Embayment. These values are comparable with those found in shelf and coastal areas of the southern and eastern Pacific (MONTECINO et al., 2004; PENNINGTON et al., 2006).

As in the Cabo Frio region, the other systems usually present highest upwelling intensity during the summer season. The exception is the Benguela system where it occurs during the winter, presenting a disassociation of maximum upwelling intensity and maximum concentrations of chlorophyll. 
Patti et al. (2008) suggested that some areas of the Benguela system maintain the elevated upwelling intensity and chlorophyll concentrations because its coastal area is extensive and wide. In contrast, the Peruvian and Brazilian coasts present a narrow continental shelf that facilitates the oceanic loss of primary biomass. The embayments along the Benguela system are a perfect place for plankton growth and elevated primary production. This is also observed in the Cabo Frio region; more precisely in the embayment situated in the Marine Extractive Reserve of Arraial do Cabo.

In the Humboldt and Cabo Frio systems, the primary biomass peaks during spring and summer (September to March) whereas it is well defined during spring in the California system and during summer in the Canaries. Primary production in the Peru system is lower than in the northern Benguela area (BAKUN; WEEKS, 2008) but corresponds to around $0.5 \%$ of global production with

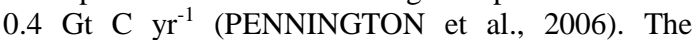
primary production in the surface waters of the Cabo Frio system is equivalent to that in the Peruvian coastal upwelling (GUENTHER et al., 2008). However, the former is at least one order of magnitude lower than the latter if the euphotic zone and upwelling area are considered. Estimates of annual primary production and remote sensing applications on a regional scale require consideration, not only of alongshore variability, but also of vertical variability in these surface waters (MONTECINO et al., 2004). Data considering all this variability are still scarce for the Brazilian upwelling system.

Heterotrophic bacterioplankton is important in inducing primary production, recycling compounds produced by autotrophic organisms and consuming organic material (CARVALHO; GONZALEZRODRIGUEZ, 2004; YOSHINAGA et al., 2008; PEREIRA et al., 2009b). Heterotrophic bacterial activity did not change during upwelling (spring/summer) and subsidence (autumn/winter) seasons. Meanwhile, bacterial growth could be suppressed during the presence of SACW possibly due to its low temperature (GUENTHER et al., 2008). Besides Bacteria, Archaea are also important to carbon and nitrogen cycles in both the superficial and deep waters of the region (CURY et al., 2011). Meanwhile, the role of individual bacterial subgroups in oceanic food webs and biogeochemical cycles requires more research (YOKOKAWA; NAGATA, 2010).

The Cabo Frio region is influenced by coastal, tropical and subtropical waters (VALENTIN, 1984b; PEREIRA et al., 2008). The contribution of these different water types induces spatial and temporal variation in composition and abundance of bacterioplankton, phytoplankton and zooplankton, and community changes correlate with upwelling events
(VALENTIN et al., 1987b; CURY et al., 2011). Valentin (2001) suggested that drift currents carry larvae out to the open sea which later return as adults to coastal surface waters when the duration of the upwelling events corresponds to the duration of the zooplankton life cycle. In relation to trophic groups, during maximum phytoplankton concentration, zooplankton is dominated by opportunistic herbivores and carnivores. After that, there is a succession of facultative herbivores, predators, detritivores and omnivores.

\section{Benthic Communities}

Benthic biomass usually reflects the production of its surrounding water since detritus not mineralized by the microbial loop in the water column are transferred to benthic organisms (POLIS et al., 1997). Marine snow is a source of microbes and microorganisms are also observed in benthic systems of the Cabo Frio upwelling region. There is considerable heterotrophic prokaryotic activity in algae turfs and in the pheophyte Sargassum, being associated with trap detritus in the former and with primary production of the macroalgae in the latter (COELHO-SOUZA et al., 2012). Furthermore, a great diversity of Archaea, Bacteria and Algal plastids are associated with the reef-building corals Siderastrea stellata and Mussismilia hispida (LINS-DE-BARROS et al., 2010). In the Chilean upwelling system, suboxic natural conditions in sediment favor the development of the giant bacteria Thioploca (ESCRIBANO et al., 2004).

In the Cabo Frio system, algal tropical species are adapted to cold water with a reproductive peak during the upwelling season (GUIMARAENS; COUTINHO, 1996). Peaks in Ulva sp. abundance occurs during the upwelling season (GUIMARAENS et al., 2005) and SACW changes its carbon and nitrogen isotopic composition (FERRAZ et al., 2004). In addition, SACW provides conditions for completion of the temperate kelp Laminaria abyssalis life cycle and maximum growth of sporophytes in banks situated at $50-110 \mathrm{~m}$ depth (YONESHIGUE-VALENTIN, 1990).

The highest photosynthetic activity of epilitical algal turf occurs during summer and growth is regulated by reef fishes' herbivory (FERREIRA et al., 1998). The soft coral Palythoa caribaeorum is conspicuous at sites with lesser upwelling influence and it seems to determine reef fishes' zonation patterns (MENDONÇA-NETTO et al., 2008). The small scale tropical and subtropical features in the Cabo Frio region (Fig. 3) favor a great species richness of reef fishes on the southeastern/southern Brazilian coast (FLOETER et al., 2001). SACW also seems to 
promote the dominance of predators such as crabs and sea stars (DE LÉO; PIRES-VANIN, 2006), great genetic variation in populations of the sponge Chondrilla (ZILBERG et al., 2006) and a great diversity of ascidian species (ROCHA; COSTA, 2005).

Sargassum sp. is a seasonal macroalga directly associated with the upwelling season (GUIMARAENS et al., 2008). This macroalga increases the rocky shore complexity, abundance and diversity of benthic invertebrates and reef fishes (FONSECA-GENEVOIS et al., 1998; ORNELLAS; COUTINHO, 1998). Abundance of the invasive bivalve Isognomon bicolor is positively associated with Sargassum sp. coverage, probably because the Sargassum sp. canopy protects bivalves against predation (LÓPEZ; COUTINHO, 2010). However, independently of the macroalga coverage, I. bicolor was less consumed than the exotic mussel Perna perna, considered an old introduction. It suggests that native predators (whelks) are still adapting their foraging skills to handle the more recent invader, $I$. bicolor (LÓPEZ et al., 2010).

Temperature is also a physical factor influencing the ecology and physiology of benthic invertebrates. For example, two rocky intertidal predators fed more intensely in laboratory experiments simulating warm waters. However, growth was similar in both cold and warm waters probably due to a decrease in metabolic costs in colder conditions (SANFORD, 2002).

Current action controls the composition and morphology of epibenthic biota (LEVINTON, 1982), as well as larvae transport (YOSHINAGA et al., 2010). SACW was negatively associated with abundance and settling of the barnacles Tetraclita stalactifera and Chthamalus bisinuatus larvae. Nauplii abundance was high during summer contrasting with the highest concentrations of cypris during the subsidence period (SKINNER; COUTINHO, 2002). After larval settlement, the Tetraclita stalactifera growth was no different whether at sites under lesser or greater upwelling influence (SKINNER et al., 2007). These results seem to agree with the expected pattern of shoreward larval transport with a relaxation of wind forcing after a coastal upwelling event, as observed in the California system (ROUGHGARDEN et al., 1988). However, future studies need to focus on larval transport linked to physical oceanographic conditions so as better to understand the influence of upwelling on the recruitment of different marine species in the Cabo Frio system.

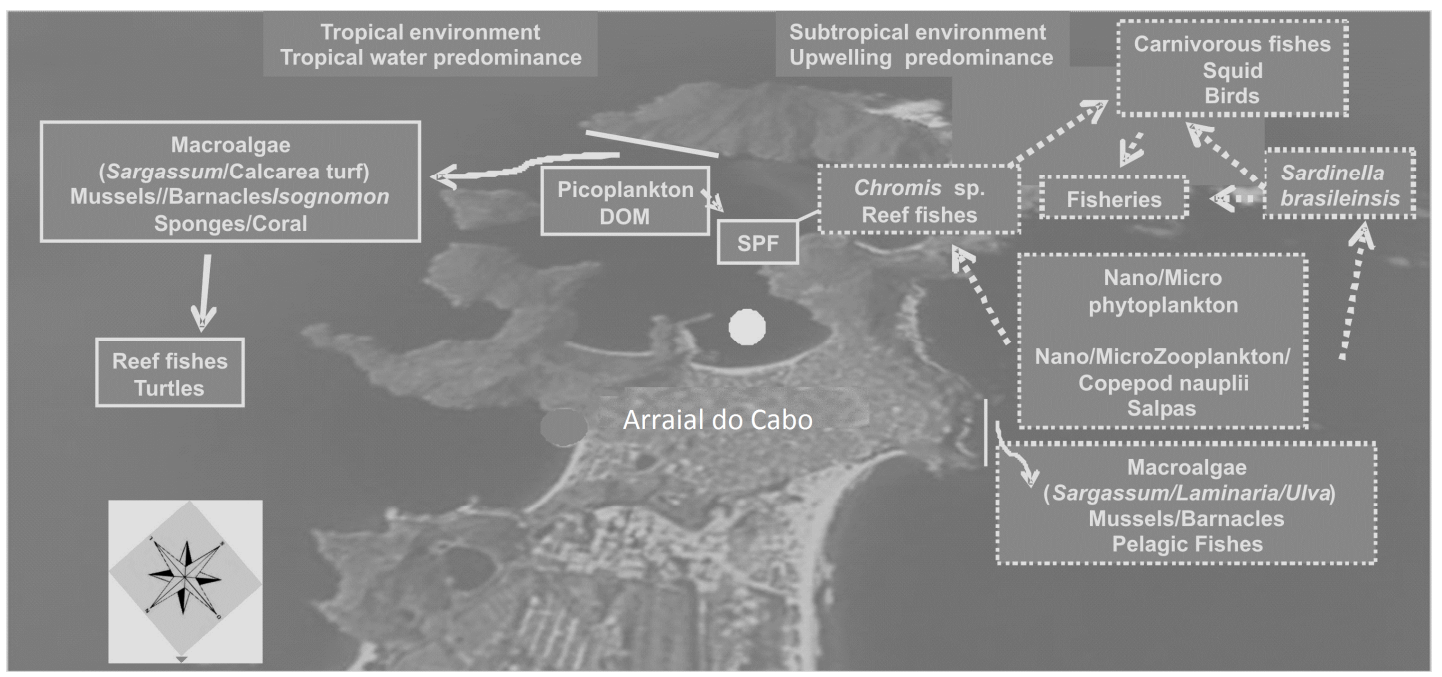

Fig. 3. Simplified trophic web in tropical (inside the Cabo Frio embayment) and subtropical (outside the Cabo Frio embayment) environments found in the Marine Extractive Reserve of Arraial do Cabo (Cabo Frio region). Continuous lines indicate a tropical web and the discontinuous line is associated with upwelling dynamics. White circle indicates impacted anthropogenic areas. $\mathrm{DOM}=$ dissolved organic matter. SPF $=$ small pelagic fishes. During the presence of Coastal Water a detritus web prevails. See more details in the text. Modified from Google Earth ${ }^{\circledast}$. 
Nekton, Trophodynamics and Fishery Production

Upwelling systems occupy but $1 \%$ of the total oceanic area though they represent $20 \%$ of world fisheries' production, a volume one hundred times greater than the annual global average. It has been estimated that $15-30 \%$ of primary production sustains fishery production (CURY et al., 2000). Small pelagic fishes occupy intermediate trophic levels and they are essential to biomass stocks and energy transfer. Predatory fishery can change the abundance, composition and distribution of pelagic communities. The management of small pelagic fishes in upwelling areas is crucial for sustainable fishery production (RYKACZEWSKI; CHECKLEY JR., 2008). However, fishery management should be based on system-specific knowledge (MOLONEY et al., 2005).

Cury et al. (2000) showed that in the Canaries, Benguela, California and Humboldt upwelling systems the natural mortality of pelagic fishes was higher than that due to anthropogenic fisheries. For example, $55 \%$ of pelagic fishes were eaten by top predators like sharks in the Benguela system. Considering all four systems, $31 \%$ of these small pelagic fishes were preyed on by large pelagic fishes, $27 \%$ were captured by fishery activities, $23 \%$ predated by demersal fishes and $19 \%$ consumed by mammals and birds. Predation by birds is essential to nutrient cycling in the Peruvian upwelling system (JAHNCKE et al., 2004). In the Cabo Frio region, abundance of nekton provides an important food source for seabirds (as Sula leucogaster and Larus argentatus) over the inner shelf of Arraial do Cabo (VALENTIN, 2001).

In upwelling systems, fish biomass tends to be dominated by a sardine or anchovy species. The Peru upwelling system presents the higher fishery production exactly because of the presence of both Sardinela aurita and Engraulis ringens species (MOLONEY et al., 2005). The alternation of dominance between these fishes restructures the ecosystem from phytoplankton to top predators (ALHEIT; NIQUEN, 2004). Anchovy shares the carbon fixed by phytoplankton with copepods but predatory fishery on Engraulis ringens increases carbon fluxes from copepods to euphasiids and sardines, as well as detritus flocculation to the benthic system (CURY et al., 2000).

Following Rykaczewski and Checkley Jr. (2008), anchovy and sardine do not occupy the same niche. While anchovy population growth occurs during strong upwelling periods, sardine grows up to four times more during a weak upwelling period. Moreover, sardine spawning occurs in oceanic waters and both larvae and adults are specialized in feeding on plankton with diameters of less than $10 \mu \mathrm{m}$. Anchovy spawns close to the coast and is able to eat larger preys. The trophic position of anchovy and sardine as small pelagic fishes regulates trophic pyramids since both are plankton consumers and are preyed on by top predators.

In the northwestern region of Africa, Sardinella aurita thrives with intense upwelling and high primary production (ZEEBERG et al., 2008). In the Californian region, microphytoplankton is dependent on oceanographic conditions that structure the trophic system. It regulates feeding places and the diets of nekton species, supporting profitable fishery stocks (BRODEUR; PEARCY, 1992). On the other hand, Wilson et al. (2008) suggested that the transport of fish larvae is more closely associated with the seasonal spawning cycle than with coastal oceanographic migration events. Superficial water temperature, latitude and depth are also important to explain fish larvae concentration (AUTH, 2008).

In the Cabo Frio system, Sardine (Sardinella brasiliensis) predominates in fishery production mainly in the Arraial do Cabo marine protection area. The spawning peaks occur during summer, in stable and nutrient-rich environments, influenced by both SACW and BC close the coast (BAKUN; PARRISH, 1990). The upwelling process is also important to the reproduction activity of other fishes, for example Diplodus argenteus (silver porgy), that spawns and recruits between August and March and presents optimum growth in $18-20^{\circ} \mathrm{C}$ waters (DAVID et al., 2005).

In the Cabo Frio region, sardine stocks collapsed during the 1970s and this was attributed to overfishing. However, Matsuura (1996) suggested that the decline in catches was caused by a recruitment failure of some year-classes, owing to a low frequency of upwelling events. In this situation an increase in the captures of species on higher trophic levels was observed, including oceanic fishes such as tunas and sharks. Thereafter, a decrease of predation on small pelagic fishes increased mackerel (Scomber sp.) biomass (VASCONCELLOS; GASALLA, 2001).

Other important species for local fishery activities are Pomatomus saltatrix, Trichiurus lepturus, Enthynmus alleterattus, Scomber japonicas, Caranx latus and Coryphaena hippurus. Inside the Arraial do Cabo embayment, where there is less influence of upwelled waters, the tide cycle seems to be important for fishery activities. The number of individuals, species richness and diversity were higher during low tide as a reflection of the abundance of juvenile individuals (GAELZER; ZALMON, 2008).

Squids are also important fishery items and are associated with upwelling dynamics (COSTA; FERNANDES, 1993). However, high pollutant concentrations in squids and marine mammals (such as whales and dolphins like Stenella frontaris, Pseudorca crassidens, Tursiops truncatus, Steno bredanensis and 
Delphinus delphis) from the Rio de Janeiro coast are associated with the rising of SACW (DORNELES et al., 2007; 2010).

\section{Global Changes and Local Impacts}

Since upwelling phenomena are dependent on the physical interaction between atmosphere and ocean, Bakun (1990) considered that the consequences of global warming in upwelling ecosystems are particularly uncertain but potentially dramatic. If winds increase their intensity and frequency, upwelling events must be intensified. An increase in wind intensity and primary production has been suggested during the last 40 years in the central equatorial Pacific Ocean. However, great changes may have occurred during the past $250 \mathrm{kyr}$, when upwelling rates were 1.5 times lower than at the present (LYLE et al., 1992).

Diffenbaugh et al. (2004) followed Bakun's (1990) studies and proposed that land-cover feedbacks enhance the effects of $\mathrm{CO} 2$ on the California Current's activity. Changes in land-cover are causing alterations in the intensity and seasonality of upwelling that would likely impact both marine and terrestrial environments. A month's delay of favorable winds reduced concentration of nutrients, chlorophyll $a$ and recruitment of barnacles and mussels in the California upwelling system (BARTH et al., 2007). Land use is increasing in the Cabo Frio region.

There is a long-term variation in upwelling magnitude beyond that related to anthropogenic $\mathrm{CO} 2$ increase and its variability is also associated with "El Niño" or "La Ninã" events (FIELD et al., 2006). "El Niño" events have usually been associated with upwelling in the Humboldt system during the last seven thousand years (LOUBERE et al., 2003). In the Cabo Frio system, Laslandes et al. (2006) suggested that the influence of "El Niño" events has been increasing over the last four thousand years and upwelling processes must have been associated with the predominance of northeasterly winds for about the last 2,400 years. Moreover, climatic changes in the last 1,000 to 3,000 years could have intensified upwelling events during the last seven hundred years (MAHIQUES et al., 2005). It has been suggested that the upwelling events in the Benguela system started ten million years ago (SIESSER, 1980). In the Canaries system, it has been estimated that upwelling has intensified over the last 15-24 thousand years (SICRE et al., 2001). In the California system, a regular upwelling frequency has been projected back over the last 120 thousand years (KILLINGLEY; BERGER, 1979).

An increase in upwelling intensity has been suggested for the Canary (MCGREGOR et al., 2007) and Benguela systems and may be a function of the superficial Atlantic circulation (MARLOW et al., 2000). However, a rise in temperature and water level has been reported on the southwestern coast of the USA (ROEMMICH, 1992). Macrozooplankton has decreased in the last 50 years and it has been suggested that a higher surface water temperature contrasting with the higher upwelling intensity might have increased water stratification. It must have limited the ascension of nutrients to the euphotic layer (ROEMMICH; MCGOWAN, 1995). In the Cabo Frio system, no tendency to an increase in wind or upwelling intensities was observed between 1970 and 1993 (Elias, unpublished data).

Chan et al. (2008) reported a change in current dynamics facilitating anoxic and subanoxic conditions that could be the cause of the mass mortality of fishes and invertebrates in the California system (GRANTHAM et al., 2004). Despite no anoxic conditions' having been observed in SACW, there are human effects such as the sewage impact in the Marine Extractive Reserve of Arraial do Cabo that need to be controlled (PEREIRA et al., 2010; CURY et al., 2011). Further, the emission of chemical substances could undergo an increase in their toxicity by microbial transformation and thus affect resident communities (SOARES, 2008).

Port activity, the introduction of exotic species (FERREIRA et al., 2004) and the extraction of live and inert aquaria supplies are other threats to local biodiversity (GASPARINI et al., 2005). The traditional, artisan fishery led to the creation of the Marine Extractive Reserve of Arraial do Cabo in 1997. However, adequate management is still necessary to solve local conflicts. Protection areas have been considered a possible solution for marine Brazilian biodiversity maintenance but adequate management strategies are not usually implemented in these areas (FLOETER et al., 2006).

\section{Concluding Remarks}

The Cabo Frio system presents lower Ekman transport, nutrient concentration, primary biomass and productivity as well as fishery production than the other main upwelling regions. This probably has to do with the Earth's rotation since the main upwelling areas are on the western side of the African and American continents. Moreover, the highest upwelling intensity is found in the southern hemisphere.

Some ecological patterns typical of upwelling ecosystems are also observed in the Cabo Frio region in spite of the need for further study. As shown in table 1, the Cabo Frio system is the subject of considerably fewer publications than the main upwelling regions, even if its smaller area is taken into account. However, considering the extension of the Brazilian upwelling system - from the State of Espírito 
Santo to that of Rio Grande do Sul - the Cabo Frio region concentrates almost $35 \%$ of all the studies written on the upwelling environments of the Brazilian coast.

Reports on the Cabo Frio system have focused on the environmental sciences/ecology, and marine biology sciences, as is also to be observed in studies on the African and Chilean upwelling systems. Publications from these regions also focus on oceanography sciences, just as do those on the California and Peru systems. However, studies on the Cabo Frio system in the meteorological and atmospheric sciences are frequent whereas zoological/botanical reports are scarce. The ecological implications of its local diversity deserve to be more fully described since the Cabo Frio region presents environments with both tropical and subtropical features (Fig. 3). Studies of the Brazilian upwelling began more recently than did those on the main upwelling systems - and knowledge of these more adequately studied areas could improve, with due local adaptation, our understanding of the Cabo Frio system.

Table 1. Number of papers published on the world's main coastal upwelling areas and the major subject areas with which they deal, and those on the Brazilian and Cabo Frio (CF) region, up to December/2011. Source: ISI Web of Knowledge ${ }^{\circledR}$.

\begin{tabular}{lccccc}
\hline \hline $\begin{array}{l}\text { Subject } \\
\text { Area/System }\end{array}$ & California & Africa & Chile & Peru & $\begin{array}{c}\text { Brazil } \\
(\mathbf{C F})\end{array}$ \\
\hline Oceanography & 883 & 363 & 261 & 196 & $76(21)$ \\
Marine Biology & 779 & 436 & 273 & 142 & $95(33)$ \\
Geology & 759 & 507 & 208 & 192 & $94(19)$ \\
Environmental & 558 & 470 & 253 & 209 & $92(38)$ \\
Sciences/Ecology & & & & & \\
\hline Total & $\mathbf{1 7 4 4}$ & $\mathbf{1 3 1 7}$ & $\mathbf{5 3 5}$ & $\mathbf{4 9 3}$ & $\mathbf{2 6 9}(\mathbf{9 3})$ \\
\hline
\end{tabular}

The Cabo Frio region calls for more research into its oceanographic and biological variability, especially of its inter-annual and decennial changes, as well as into the anthropogenic and natural influences that affect it. Studies coupling nekton and larval transport to oceanic dynamics are few. Trophodynamics and trophic webs are not yet well established, limiting adequate fishery management since little is known of the population dynamics of fish in the Cabo Frio region. For example, the role of small pelagic fish within this system should be studied. The association between primary production and fishery stock is not as well established in the Cabo Frio system as it is for the other main upwelling areas.

The potential influence of global warming on Cabo Frio biodiversity is still not sufficiently understood. Studies on local and regional variability are to be encouraged, particularly those on links in the ecosystem related to physical-chemical-biological interactions. Temperature should be considered a crucial aspect since it is reflected in physical actions and determines biological adaptation and physiology as well as representing the main topic of discussion in an age of global warming. Studies on the coupling of pelagic and benthic environments are scarce and evaluation of global and local impacts is lacking. The presence of tropical and subtropical environments in close association is a feature of this region. Multidisciplinary studies on increased spatial and temporal scales are, therefore, needed to lay a better foundation for adequate management of biodiversity and of decision-making processes.

\section{ACKNOWLEDGEMENTS}

We thank Leandro Calado, Laura Zoffoli, Bárbara Lage, Eliane Gonzalez Rodriguez, Maria Helena Baeta Neves, Rafael Matos, Eduardo Netto, Lúcia Artusi, Tânia Oda and Jean Valentin for discussion and references. We also thank all the anonymous referees who contributed to this final version. CAPES financed the $\mathrm{PhD}$ fellowship for the first author in PPGE/UFRJ.

\section{REFERENCES}

ALHEIT, J.; NIQUEN, M. Regime shifts in the Humboldt Current ecosystem. Prog. Oceanogr., v. 60, p. 201-222, 2004

ALLEN, J. S. Models of wind-driven on the continentalshelf. Annu. Rev. Fluid Mech., v. 12, p. 389-433, 1980.

ARNTZ, W. E.; GALLARDO, V. A.; GUTIERREZ, D.; ISLA, E.; LEVIN, L. A.; MENDO, J.; NEIRA, C.; ROWE, G. T.; TARAZONA, J.; WOLFF, M. El Niño and similar perturbation effects on the benthos of the Humboldt, California, and Benguela Current upwelling ecosystems. Adv. Geosci., v. 6, p. 243-265, 2006.

AUTH, T. D. Distribution and community structure of ichthyoplankton from the northern and central California Current in May 2004-06. Fish. Oceanogr., v. 17, p. 316331, 2008.

BAKUN, A. Global climate change and intensification of coastal ocean upwelling. Science, v. 247, p. 198-201, 1990.

BAKUN, A.; PARRISH, R. H. Comparative-studies of coastal pelagic fish reproductive habitats - the Brazilian sardine (Sardinella aurita). J. Conseil., v. 46, p. 269283, 1990.

BAKUN, A.; WEEKS, S. J. The marine ecosystem off Peru: what are the secrets of its fishery productivity and what might its future hold? Prog. Oceanogr., v. 79, p. 290299, 2008.

BARTH, J. A.; MENGE, B. A.; LUBCHENCO, J.; CHAN, F.; BANE, J. M.; KIRINCICH, A. R.; McMANUS, M. A.; NIELSEN, K. J.; PIERCE, S. D.; WASHBURN, L. Delayed upwelling alters nearshore coastal ocean ecosystems in the northern California current. P. Natl Acad. Sci. USA, v. 104, p. 3719-3724, 2007. 
BRODEUR, R. D.; PEARCY, W. G. Effects of environmental variability on trophic interactions and food web structure in a pelagic upwelling ecosystem. Mar. Ecol. Progr. Ser., v. 84, p. 101-119, 1992.

BROWN, P. C.; FIELD, J. G. Factors limiting phytoplankton production in a nearshore upwelling area. J. Plan. Res., v. 8, p. 55-68, 1986.

BRULAND, K. W.; RUE, E. L.; SMITH, G. J.; DITULLIO, G. R. Iron, macronutrients and diatom blooms in the Peru upwelling regime: brown and blue waters of Peru. Mar. Chem., v. 93, p. 81-103, 2005.

CALADO, L.; GANGOPADHYAY, A.; DA SILVEIRA, I. C. A. Feature-oriented regional modeling and simulations (FORMS) for the western South Atlantic: Southeastern Brazil region. Ocean Model., v. 25, p. 48 64, 2008.

CALADO, L.; DA SILVEIRA, I. C. A.; GANGOPADHYAY, A.; DE CASTRO, B. M. Eddyinduced upwelling off Cape Sao Tome (22 degrees S, Brazil). Cont. Shelf Res., v. 30, p. 1181-1188, 2010.

CAMPOS, E. J. D.; VELHOTE, D.; DA SILVEIRA, I. C. A. Shelf break upwelling driven by Brazil Current cyclonic meanders. Geophys. Res. Let., v. 27, p. 751754, 2000.

CARBONEL, C. Modelling of upwelling-downwelling cycles caused by variable wind in a very sensitive coastal system. Cont. Shelf Res., v. 23, p. 1559-1578, 2003.

CARVALHO, W. F.; GONZALEZ-RODRIGUEZ, E. Development of primary and bacterial productivity in upwelling waters of Arraial do Cabo, RJ (Brazil). Braz. J. Oceanogr., v. 55, p. 35-45, 2004.

CASTELAO, R. M.; BARTH, J. A. Upwelling around Cabo Frio, Brazil: The importance of wind stress curl. Geo Res. Let., v. 33, p. 2006.

CHAN, F.; BARTH, J. A.; LUBCHENCO, J.; KIRINCICH, A.; WEEKS, H.; PETERSON, W. T.; MENGE, B. A. Emergence of anoxia in the California current large marine ecosystem. Science, v. 319, p. 920, 2008.

COELHO-SOUZA, S.A.; MIRANDA, M.R.; SALGADO, L.T.; COUTINHO, R.; GUIMARAES, J.R.D. Adaptation of the $3 \mathrm{H}$-Leucine incorporation technique to measure heterotrophic activity associated with biofilm on the blades of the seaweed Sargassum spp. Microb. Ecol., DOI: 10.1007/s00248-012-0116-9, 2012.

COSTA, P. A. S.; FERNANDES, F. D. Seasonal and spatial changes of cephalopods caught in the Cabo-Frio (Brazil) upwelling ecosystem. Bull. Mar. Sci., v. 52, p. 751-759, 1993.

CURY, P.; BAKUN, A.; CRAWFORD, R. J. M.; JARRE, A.; QUIÑNOS, R. A.; SHANNON, L. J.; VERHEYUE, H. M. Small pelagics in upwelling systems: patterns of interaction and structural changes in "wasp-waist" ecosystems. ICES J. Mar. Sci. J. Conseil., v. 57, p. 603-618, 2000.

CURY, J. C.; ARAUJO, F. V.; COELHO-SOUZA, S. A.; PEIXOTO, R. S.; OLIVEIRA, J. A. L.; SANTOS, H. F.; ÁVILA, A. M. R.; ROSADO, A. S. Microbial diversity of a Brazilian coastal region influenced by an upwelling system and anthropogenic activity. PLoS ONE, v. 6, e16553. DOI:10.1371/journal.pone.0016553, 2011.

DALY, K. L.; SMITH, W. O. Physical-biological interactions influencing marine plankton production. Annu. Rev. Ecol. Syst., v. 24, p. 555-585, 1993.
DAVID, G. S.; COUTINHO, R.; QUAGIO-GRASSIOTTO, I.; VERANI, J. R. The reproductive biology of Diplodus argenteus (Sparidae) in the coastal upwelling system of Cabo Frio, Rio de Janeiro, Brazil. Afr. J. Mar. Sci., v. 27, p. 439-447, 2005.

DE LEO, F. C.; PIRES-VANIN, A. M. S. Benthic megafauna communities under the influence of the South Atlantic Central Water intrusion onto the Brazilian SE shelf: A comparison between an upwelling and a non-upwelling ecosystem. J. Mar Syst., v. 60, p. 268-284, 2006.

DENMAN, K. L.; GARGETT, A. E. Biological physical interactions in the upper ocean - the role of vertical and small-scale transport processes. Annu. Rev. Fluid Mech., v. 27, p. 225-255, 1995.

DIFFENBAUGH, N. S.; SNYDER, M. A.; SLOAN, L. C. Could $\mathrm{CO}_{2}$-induced land-cover feedbacks alter nearshore upwelling regimes? P. Natl Acad. Sci. USA, v. 101, p. 27-32, 2004.

DORNELES, P. R.; LAILSON-BRITO, J.; DOS SANTOS, R. A.; DA COSTA, P. A. S.; MALM, O.; AZEVEDO, A. F.; TORRES, J. P. M. Cephalopods and cetaceans as indicators of offshore bioavailability of cadmium off Central South Brazil Bight. Environ. Pollut., v. 148, p. 352-359, 2007.

DORNELES, P. R.; LAILSON-BRITO, J.; DIRTU, A. C.; WEIJS, L.; AZEVEDO, A. F.; TORRES, J. P. M.; MALM, O.; NEELS, H.; BLUST, R.; DAS, K.; COVACI, A. Anthropogenic and naturally-produced organobrominated compounds in marine mammals from Brazil. Environ. Internat., v. 36, p. 60-67, 2010.

DUGDALE, R. C.; WILKERSON, F. P. Silicate regulation of new production in the equatorial Pacific upwelling. Nature,v. 391, p. 270-273, 1998.

ESCRIBANO, R.; DANERI, G.; FARIAS, L.; GALLARDO, V. A.; GONZALEZ, H. E.; GUTIERREZ, D.; LANGE, C. B.; MORALES, C. E.; PIZARRO, O.; ULLOA, O.; BRAUN, M. Biological and chemical consequences of the 1997-1998 El Nino in the Chilean coastal upwelling system: a synthesis. Deep-Sea Res Pt II, v. 51, p. 23892411, 2004.

FERRAZ, K. C; MARQUES, A. N.; RODRIGUEZ, E. G.; SANTOS, G. M.; GOMES, P. R. S. Use of C-14-AMS in the study of biological production in coastal upwelling areas. Braz. J. Phys., v. 34, p. 732-736, 2004.

FERREIRA, C. E. L.; PERET, A. C.; COUTINHO, R. Seasonal grazing rates and food processing by tropical herbivorous fishes. J. Fish Biol., v. 53, p. 222-235, 1998.

FERREIRA, C. E. L.; GONCALVES, J. E. A.; COUTINHO, R. Ship hulls and oil platforms as potential vectors to marine species introduction. J. Coast. Res., v. 3, p. 1340-1345, 2004

FIELD, D. B.; BAUMGARTNER, T. R.; CHARLES, C. D.; FERREIRA-BARTRINA, V.; OHMAN, M. D. Planktonic foraminifera of the California Current reflect 20th-century warming. Science, v. 311, p. 63-66, 2006.

FLOETER, S. R.; GUIMARAES, R. Z. P.; ROCHA, L. A.; FERREIRA, C. E. L.; RANGEL, C. A.; GASPARINI, J. L. Geographic variation in reef-fish assemblages along the Brazilian coast. Global Ecol. Biogeogr., v. 10, p. 423-431, 2001.

FLOETER, S. R.; HALPERN, B. S.; FERREIRA, C. E. L. Effects of fishing and protection on Brazilian reef fishes. Biol. Conserv., v. 128, p. 391-402, 2006. 
FONSECA-GENEVOIS, V.; ALMEIDA, T. C. M COUTINHO, R.; SILVA, F. F. Efeito de um banco de Sargassum furcatum Küetzing sobre a meiofauna no infralitoral da ilha do Cabo Frio - Rio de Janeiro- Brasil. Acta Biol. Leopold., v. 20, p. 187-199, 1998.

FRANCHITO, S. H.; RAO, V. B.; STECH, J. L.; LORENZZETTI, J. A. The effect of coastal upwelling on the sea-breeze circulation at Cabo Frio, Brazil: a numerical experiment. Ann. Geophys-Atmos. Hydro Space Sci., v. 16, p. 866-881, 1998.

FRANCHITO, S. H.; RAO, V. B.; ODA, T. O.; CONFORTE, J. C. An observational study of the evolution of the atmospheric boundary-layer over Cabo Frio, Brazil. Ann. Geophys., v. 25, p. 1735-1744, 2007.

FRANCHITO, S. H.; ODA, T. O.; RAO, V. B.; KAYANO, M. T. Interaction between coastal upwelling and local winds at Cabo Frio, Brazil: An observational study. J. Appl. Meteorol. Climatol., v. 47, p. 1590-1598, 2008.

GAELZER, L. R.; ZALMON, I. R. Tidal influence on surf zone ichthyofauna structure at three sandy beaches, Southeastern Brazil. Braz. J. Oceanogr.,v. 56, p. 165177,2008

GASPARINI, J. L.; FLOETER, S. R.; FERREIRA, C. E. L.; SAZIMA, I. Marine ornamental trade in Brazil. Biol. Conserv., v. 14, p. 2883-2899, 2005.

GONZALEZ-RODRIGUEZ, E. A ressurgência de Cabo Frio (RJ, Brasil): fertilidade e fatores nutricionais limitantes da biomassa fitoplanctônica. Rev. Bras. Biol., v. 51, p. 471-486, 1991.

GONZALEZ-RODRIGUEZ, E. Yearly variation in primary productivity of marine phytoplankton from Cabo Frio (RJ, Brazil) region. Hydrobiol., v. 294, p. 145-156, 1994.

GONZALEZ-RODRIGUEZ, E.; MAESTRINI, S. Y. Nutrient enrichment of Cabo Frio (Brasil) sea water for phytoplankton mass production. Hydrobiol., v. 111, p. 49-56, 1984

GONZALEZ-RODRIGUEZ, E.; VALENTIN， J. L.; ANDRÉ, D. L.; JACOB, S. A. Upwelling and downwelling at Cabo Frio (Brazil): comparison of biomass and primary production responses. J. Plank. Res., v. 14, p. 289-306, 1992.

GONZALEZ-RODRIGUEZ, E.; TENENBAUM, D. R. Variação diurna da capacidade fotossintética do fitoplâncton de Cabo Frio (RJ, Brasil). Acta Biol Leopold., v. 17, n. 1, p. 35-52, 1995.

GRANTHAM, B. A.; CHAN, F.; NIELSEN, K. J.; FOX, D S.; BARTH, J. A.; HUYER, A.; LUBCHENCO, J.; MENGE, B. A. Upwelling-driven nearshore hypoxia signals ecosystem and oceanographic changes in the northeast Pacific. Nature, v. 429, p. 749-754, 2004.

GUENTHER, M.; GONZALEZ-RODRIGUEZ, E.; CARVALHO, W. F.; REZENDE, C. E.; MUGRABE, G.; VALENTIN, J. L. Plankton trophic structure and particulate organic carbon production during a coastal downwelling-upwelling cycle. Mar. Ecol. Prog. Ser., v. 363, p. 109-119, 2008

GUIMARAENS, M. A.; COUTINHO, R. Spatial and temporal variation of benthic marine algae at the $\mathrm{Cabo}$ Frio upwelling region, Rio de Janeiro, Brazil. Aquat. Bot., v. 52, p. 283-299, 1996.

GUIMARAENS, M. A.; PAIVA, A. D.; COUTINHO, R. Modeling Ulva spp. dynamics in a tropical upwelling region. Ecol. Model., v. 188, p. 448-460, 2005.
GUIMARAENS, M. A.; GONCALVES, J. E. A.; LOURENCO, S. O.; COUTINHO, R. Sensitivity analyses of population biomass dynamics for Ulva spp. and Sargassum furcatum at the Cabo Frio upwelling region of Brazil. J. Biol. Syst., v. 16, p. 579-596, 2008.

HUTCHINS, D. A.; BRULAND, K. W. Iron-limited diatom growth and Si:N uptake ratios in a coastal upwelling regime. Nature, v. 393, p. 561-564, 1998.

JAHNCKE, J.; CHECKLEY, D. M.; HUNT, G. L. Trends in carbon flux to seabirds in the Peruvian upwelling system: effects of wind and fisheries on population regulation. Fish. Oceanogr., v. 13, p. 208-223, 2004.

KAMPEL, M.; LORENZETTI, J. A; SILVA JR.; C. L. Observação por satélite de ressurgências na costa S-SE brasileira. In: CONGRESSO LATINO-AMERICANO SOBRE CIÊNCIAS DO MAR (COLACMAR), 7, 1997,Santos, SP. p.38-40, 1997.

KILLINGLEY, J. S.; BERGER, W. H. Stable isotopes in a mollusk shell - detection of upwelling events. Science, v. 205, p. 186-188, 1979.

LASLANDES, B; SYLVESTRE, F; SIFEDDINE，A; TURCQ, B.; ALBUQUERQUE, A. L. S.; ABRAO, J. Enregistrement de la variabilité hydroclimatique au cours des 6500 dernières années sur le littoral de Cabo Frio (Rio de Janeiro, Brésil). CR Geosci., v. 338, p. 667-675, 2006.

LEHMANN, A.; MYRBERG, K. Upwelling in the Baltic Sea - A review. J. Mar. Syst., v. 74, p. 3-12, 2008.

LEVINTON, J. S. Marine Ecology. New Jersey: PrenticeHall., 1982. 526 p.

LINS-DE-BARROS, M. M.; VIEIRA, R. P.; CARDOSO, A. M.; MONTEIRO, V. A.; TURQUE, A. S.; SILVEIRA, C. B.; ALBANO, R. M.; CLEMENTINO, M. M.; MARTINS, O.B. Archaea, bacteria and algal plastids associated with the reef-building corals Siderastrea stellata and Mussismilia hispida from Buzios, South Atlantic Ocean, Brazil. Microb. Ecol., v. 59, p. 523-532, 2010.

LÓPEZ, M. S.; COUTINHO, R. Positive interaction between the native macroalgae Sargassum sp. and the exotic bivalve Isognomon bicolor? Braz. J. Oceanogr., v. 58, p. 69-72, 2010.

LÓPEZ, M. S.; COUTINHO, R.; FERREIRA, C. E. L.; RILOV, G. Predator-prey interactions in a bioinvasion scenario: differential predation by native predators on two exotic rocky intertidal bivalves. Mar. Ecol. Prog. Ser., v. 403, p. 101-112, 2010

LOUBERE, P.; RICHAUD, M.; LIU, Z. Y.; MEKIK, F. Oceanic conditions in the eastern equatorial Pacific during the onset of ENSO in the Holocene. Quat. Res., v. 60 , p. $142-148,2003$.

LYLE, M. W.; PRAHL, F. G.; SPARROW, M. A. Upwelling and productivity changes inferred from a temperature record in the central equatorial pacific. Nature, v. 355, p. 812-815, 1992.

MAHIQUES, M. M.; BICEGO, M. C.; DA SILVEIRA, I. C. A.; SOUSA, S. H. M.; LOURENCO, R. A.; FUKUMOTO, M. M. Modern sedimentation in the Cabo Frio upwelling system, southeastern Brazilian shelf. An. Acad. Bras. Ciênc., v. 77, p. 535-548, 2005.

MARLOW, J. R.; LANGE, C. B.; WEFER, G.; ROSELLMELE, A. Upwelling intensification as part of the Pliocene-Pleistocene climate transition. Science, v. 290, p. 2288, 2000. 
MATSUURA, Y. A probable cause of recruitment failure of the Brazilian sardine Sardinella aurita population during the 1974/75 spawning season. South Afr. J. Mar. Sci., v. 17 , p. $29-35,1996$.

MCGREGOR, H. V.; DIMA, M.; FISCHER, H. W.; MULITZA, S. Rapid 20th-Century increase in coastal upwelling off Northwest Africa. Science, v. 315, p. $637-$ 639, 2007.

MCMANUS, G. B.; COSTAS, B. A.; DAM, H. G.; LOPES, R. M.; GAETA, S. A.; SUSINI, S. M.; ROSETTA, C. H. Microzooplankton grazing of phytoplankton in a tropical upwelling region. Hydrobiol., v. 575, p. 69-81, 2007.

MENDONÇA-NETO, J. P.; FERREIRA, C. E. L.; CHAVES

L. C. T.; PEREIRA, R. C. Influence of Palythoa caribaeorum (Anthozoa, Cnidaria) zonation on site attached reef fishes. An. Acad. Bras. Ciênc., v. 80, p. 495-513, 2008.

MILLER, C. B. Biological Oceanography. Malden, MA Blackwell Pub., 2004. 402 p.

MOLONEY, C. L.; JARRE, A.; ARANCIBIA, H.; BOZEC, Y. M.; NEIRA, S.; ROUX, J. P.; SHANNON, L. J. Comparing the Benguela and Humboldt marine upwelling ecosystems with indicators derived from intercalibrated models. Ices J. Mar. Sci., v. 62, p. 493-502, 2005.

MONTECINO, V.; ASTORECA, R.; ALARCON, G.; RETAMAL, L.; PIZARRO, G. Bio-optical characteristics and primary productivity during upwelling and non-upwelling conditions in a highly productive coastal ecosystem off central Chile $\left(\sim 36^{\circ} \mathrm{S}\right)$. Deep-Sea Res. Pt II, vol. 51, p. 2413-2426, 2004.

ODUM, E. P. Ecologia. Rio de Janeiro: Guanabara, 1983. 434 p. (Titulo original: Basic Ecology).

ORNELLAS, A. B.; COUTINHO, R. Spatial and temporal patterns of distribution and abundance of a tropical fish assemblage in a seasonal Sargassum bed, Cabo Frio Island, Brazil. J Fish Biol., v. 53, p. 198-208, 1998.

PATTI, B.; GUISANDE, C.; VERGARA, A. R.; RIVEIRO, I.; MANEIRO, I.; BARREIRO, A.; BONANNO, A.; BUSCAINO, G.; CUTTITTA, A.; BASILONE, G.; MAZZOLA, S. Factors responsible for the differences in satellite-based chlorophyll a concentration between the major global upwelling areas. Estuar. Coast. Shelf Sci., v. 76, p. 775-786, 2008.

PELEGRI, J. L.; ARISTEGUI, J.; CANA, L.; GONZALEZDAVILA, M.; HERNANDEZ-GUERRA, A.; HERNANDEZ-LEON, S.; MARRERO-DIAZ, A.; MONTERO, M. F.; SANGRA, P.; SANTANACASIANO, M. Coupling between the open ocean and the coastal upwelling region off northwest Africa: water recirculation and offshore pumping of organic matter. $\mathbf{J}$. Mar. Syst., v. 54, p. 3-37, 2005

PENNINGTON, J. T.; MAHONEY, K. L.; KUWAHARA, V. S.; KOLBER, D. D.; CALIENES, R.; CHAVEZ, F. P. Primary production in the eastern tropical Pacific: a review. Prog. Oceanogr., v. 69, p. 285-317, 2006.

PEREIRA, G.C.; COUTINHO, R.; EBECKEN, N.F.F. Data mining for environmental analysis and diagnostic: a case of upwelling ecosystem of Arraial do Cabo. Braz. J. Oceanogr., v. 56, p. 1-12, 2008.

PEREIRA, G. C.; EVSUKOFF, A.; EBECKEN, N. F. F. Fuzzy modelling of chlorophyll production in a Brazilian upwelling system. Ecol. Model., v. 220, p. 1506-1512, 2009a.
PEREIRA, G. C.; GRANATO, A.; FIGUEIREDO, A. R.; EBECKEN, N.F.F. Virioplankton abundance in trophic gradients of an upwelling field. Braz. J. Microbiol., v. 40, p. 857-865, 2009b.

PEREIRA, G. C.; FIGUEIREDO, A. R.; JABOR, P. M.; EBECKEN, N. F. F. Assessing the ecological status of plankton in Anjos Bay: a flow cytometry approach. Biogeo. Discuss., v. 7, p. 6243-6264, 2010.

POLIS, G. A.; ANDERSON, W. B.; HOLT, R. D. Toward an integration of landscape and food web ecology: The dynamics of spatially subsidized food webs. Annu. Rev. Ecol Syst., v. 28, p. 289-316, 1997.

ROCHA, R. M.; COSTA, L. V. G. Ascidians (Urochordata: Ascidiacea) from Arraial do Cabo, Rio de Janeiro, Brazil. Iheringia Sér. Zool., v. 95, p. 57-64, 2005.

RODRIGUES, R. R.; LORENZZETTI, J. A. A numerical study of the effects of bottom topography and coastline geometry on the Southeast Brazilian coastal upwelling. Cont. Shelf Res., v. 21, p. 371-394, 2001.

ROEMMICH, D. Ocean warming and sea-level rise along the southwest united-states coast. Science, v. 257, p. 373$375,1992$.

ROEMMICH, D.; MCGOWAN, J. Climatic warming and the decline of zooplankton in the California current. Science, v. 267, p. 1324-1326, 1995.

ROUGHGARDEN, J.; GAINES, S.; POSSINGHAM, H. Recruitment dynamics in complex life cycles. Science, v. 241, p. 1460-1466, 1988.

RUTLLANT, J.; MONTECINO, V. Multiscale upwelling forcing cycles and biological response off north-central Chile. Rev. Chil. Hist Nat., v.75, p. 217-231, 2002.

RYKACZEWSKI, R. R.; CHECKLEY, D. M. Influence of ocean winds on the pelagic ecosystem in upwelling regions. P. Natl Acad. Sci. USA, v. 105, p. 1965-1970, 2008

SANFORD, E. The feeding, growth, and energetics of two rocky intertidal predators (Pisaster ochraceus and Nucella canaliculata) under water temperatures simulating episodic upwelling. J. Exp. Mar. Biol. Ecol., v. 273, p. 199-218, 2002.

SICRE, M. A.; TERNOIS, Y.; PATERNE, M.; MARTINEZ, P.; BERTRAND, P. Climatic changes in the upwelling region off Cap Blanc, NW Africa, over the last 70 kyear: a multi-biomarker approach. Org.Geochem., v. 32, p. 981-990, 2001.

SIESSER, W. G. Late miocene origin of the Benguela upwelling system off northern Namibia. Science, v. 208, p. 283-285, 1980 .

SIGNORINI, S. R. Circulation and volume transport of Brazil current between cape of Sao-Tome and Guanabara bay. Deep-Sea Res., v.25, p. 481-490, 1978.

SILVA, P. P. From common property to co-management: lessons from Brazil's first maritime extractive reserve. Mar Pollut., v. 28, p. 419-428, 2004.

SKINNER, L. F.; COUTINHO, R. Preliminary results on settlement of the barnacles Tetraclita stalactifera and Chthamalus bisinuatus on a Brazilian tropical rocky shore under upwelling conditions. Invert. Reprod. Develop., v. 41, p. 151-156, 2002

SKINNER, L. F.; SIVIERO, F. N.; COUTINHO, R. Comparative growth of the intertidal barnacle Tetraclita stalactifera (Thoracica: Tetraclitidae) in sites influenced by upwelling and tropical conditions at the Cabo Frio region, Brazil. Rev. Biol.Trop., v.55, p. 71-77, 2007. 
SMITH, R. L. Upwelling: Oceanogr. Mar. Biol., v. 6, p. 1146, 1968.

SOARES, A.; GUIEYSSE, B.; JEFFERSON, B.; CARTMELL, E.; LESTER, J. N. Nonylphenol in the environment: A critical review on occurrence, fate, toxicity and treatment in wastewaters. Environ. Internat., v. 34, p. 1033-1049, 2008.

STRAMMA, L.; PETERSON, R. G. The south-Atlantic current. J. Phys. Oceanogr., v. 20, p. 846-859, 1990.

STRAMMA, L.; ENGLAND, M. On the water masses and mean circulation of the South Atlantic Ocean. J. Geophys. Res., v. 104, p. 20863-20883, 1999.

VALENTIN, J. L. Spatial structure of the zooplankton community in the Cabo-Frio region (Brazil) influenced by coastal upwelling. Hydrobiol., v. 113, p. 183-199, $1984 \mathrm{a}$

VALENTIN, J. L. Analysis of hydrobiological parameters in the Cabo Frio (Brazil) upwelling. Mar Biol., v. 82, n. 3, p. 259-276, 1984b.

VALENTIN, J. L. The Cabo Frio upwelling system, Brazil. In: SEELIGER U.; KJERFVE B. (Ed.) .Coastal marine ecosystems of Latin America. Berlin: Springer, 2001. p. 97-105, 2001

VALENTIN, J. L.; ANDRE, D. L; JACOB, S. A Hydrobiology in the Cabo Frio (Brazil) upwelling twodimensional structure and variability during a wind cycle. Cont. Shelf Res., v. 7, p. 77-88, 1987a.

VALENTIN, J. L.; MONTEIRO-RIBAS, W. M.; MUREB, M. A.; PESSOTTI, E. Some abundant zooplankton in the Cabo-Frio upwelling (Brazil). J. Plank. Res., v.9, p. 1195-1216, 1987b.

VASCONCELLOS, M.; GASALLA, M. A. Fisheries catches and the carrying capacity of marine ecosystems in southern Brazil. Fish Res., v. 50, p. 279-295, 2001.

WILSON, J. R.; BROITMAN, B. R.; CASELLE, J. E.; WENDT, D. E. Recruitment of coastal fishes and oceanographic variability in central California. Estuar.Coast Shelf Sci., v. 79, p. 483-490, 2008.
WINANT, C.D. Coastal circulation and wind-induced currents. Annu. Rev. Fluid Mech., v. 12, p. 271-301, 1980.

YONESHIGUE-VALENTIN, Y. The life-cycle of Laminaria abysallis Joly et Oliveira Filho (Laminariaceae, Laminarieales, Phaeophyta) in culture. Hydrobiol., v. 204/205, p. 461-466, 1990.

YOKOKAWA, T.; NAGATA, T. Linking bacterial community structure to carbon fluxes in marine environments. J. Oceanogr., v. 66, p. 1-12, 2010.

YOSHINAGA, M. Y.; SUMIDA, P. Y. G.; WAKEHAM, S.G. Lipid biomarkers in surface sediments from an unusual coastal upwelling area from the SW Atlantic Ocean. Org. Geochem., v. 39, p. 1386-1399, 2008.

YOSHINAGA, M. Y.; SUMIDA, P. Y. G.; DA SILVEIRA, I. C. A.; CIOTTI, A. M.; GAETA, S. A.; PACHECO, L. F. C. M.; KOETTKER, A. G. Vertical distribution of benthic invertebrate larvae during an upwelling event along transect off the tropical Brazilian continental margin. J. Mar.Syst., v.79, p. 124-133, 2010.

ZEEBERG, J; CORTEN, A; TJOE-AWIE, P.; COCA, J.; HAMADY, B. Climate modulates the effects of Sardinella aurita fisheries off Northwest Africa. Fish. Res., v. 89, n. 1, p. 65-75, 2008

ZILBERBERG, C.; SOLE-CAVA, A. M.; KLAUTAU, M. The extent of asexual reproduction in sponges of the genus Chondrilla (Demospongiae : Chondrosida) from the Caribbean and the Brazilian coasts. J. exp. Mar. Bio. Ecol., v. 336, p. 211-220, 2006.

(Manuscript received 03 November 2011; revised 18 July 2012; accepted 14 August 2012) 